\title{
Developing An Authentic Assessment Instruments of Psychomotor Domain For The Physics Learning on Measurement Materials in Class X SMA
}

\author{
Dahlia $^{1 *}$, Maison $^{2}$, Nehru $^{3}$ \\ ${ }^{1,2,3}$ Study Program of Physics Education, Faculty of Teacher Training and Education, Universitas Jambi \\ Corresponding Author. Email: Arizi_ia@yahoo.co.id
}

\section{Keywords: authentic assessment instruments, psychomotor domain}

\begin{abstract}
Practicum is a form of learning activity relates to assessment, which is part of a series of learning processes. Assessment in practicum not only consists of cognitive aspects but also emphasizes affective and psychomotor aspects. Psychomotor is a domain related to skills or ability to act after receiving learning experiences. An authentic assessment of the psychomotor domain is needed to determine each student learns and apply their learning outcomes into life. The study aimed to determine the procedure for developing an authentic assessment instrument of the psychomotor domain for physics learning on measurement material in class X SMA and describe the teacher's assessment toward the developed the authentic assessment instrument. The study used Dick and Carey developmental model consisted of ten stages. They are (1) analysis the learning objectives, (2) learning analysis, (3) analysis of students and their environment, (4) formulating specific objectives, (5) developing assessment instruments, (6) developing learning strategy, (7) developing and selecting learning materials, (8) formative evaluation, (9) revision, and (10) summative evaluation. But, the article used only nine of ten stages. The validation sheet was assessed by two expert lecturers. The product of the psychomotor assessment instrument was validated by two expert lecturers through 2 revisions. The developed instrument was tested in small groups, namely class X MIA 7, SMA N 1 Muaro Jambi. The validation obtained a total score of 136. Means, the score included in the category of $136 \leq \mathrm{N}<150$ : "Very Good." The teacher's responses were $82 \%$ of very good (positive). In short, the developed instrument was feasible to continue to trial steps. The trial to 10 students obtained a mean of 82.1. Based on the range of student scores, seven students were classified as highly skilled, and three students were classified as skilled. Based on results and discussion, it concluded that authentic assessment instruments of the psychomotor domain for the physics learning on measurement materials were feasible to use for teacher class of class X MIA in SMA N 1 Muaro Jambi.
\end{abstract}

\section{INTRODUCTION}

A shift in learning paradigm - from teachercentered learning to student-centered learning - has influenced the application of strategies and learning methods in the classroom. With this paradigm, students are no longer just receive the information from the teacher but students also play an active role in looking at information. Another implication is a change in terms of student assessment systems. Assessment is a process to measure what's know, what's do, understand, and able to apply the concepts. Today, the teacher used the test technique as an assessment method to evaluate the students' learning outcomes. This assessment is no longer able to describe the actual achievement of students. Besides, tests are unable to measure all aspects of learning as it only measures the students' abilities in the cognitive aspects.

Realizing from the weaknesses of the test techniques, it needs to find appropriate methods and assessment tools to measure the students' abilities, among cognitive, affective, and psychomotor aspects. This method or tool is discussed in a more general concept, called an authentic assessment. Abidin (2014) argues that an authentic assessment is a process of collecting various data aiming to provide an overview of student learning development. The teacher needs to know the student 
learning development to ensure that students experience the learning process correctly.

Physics is a subject that emphasizes on providing direct experience to develop competencies aiming the students can explore and understand the natural environment scientifically through a practicum. In contrast to classroom learning, practicum activities in the laboratory play an important factor in supporting the students' science learning process. Practicum is a learning activity that always relates to the assessment as part of the learning processes. Assessment in practicum not only consists of cognitive aspects but also emphasizes affective and psychomotor aspects. Practicum is closely related to skills. Measurement is a material contained in the physics syllabus at high school. Those aspects of cognitive, psychomotor, and affective are measured in this material.

Based on the observations at SMAN 1 Muaro Jambi, the implementation of the assessment in practicum activities was only limited to an observation conducted by a teacher. The teacher will note the active students. The instruments are still relatively traditional, which might not accommodate in assessing all the practicum steps. The rubric is also unspecific. Examples of research related to the development of authentic assessment are; Fatonah et al (2013) discuss "the developing authentic assessment instruments for learning science for elementary school students," meanwhile, Masyitah (2012) discuss on "the developing an authentic assessment instrument in Chemistry Subjects in SMA N 4 Kota Jambi." Suci Merinda Ovianti (2013) research on "the developing authentic assessment instruments on mathematics learning processes and results of straight-line equation materials in Class VIII SMP," but, at that time, the curriculum was KTSP.

\section{Problems Formulation}

Based on the background, the main problems of the study were:

1. What are the procedures in developing an authentic assessment instrument of the psychomotor domain for learning physics on measurement material in class X SMA?

2. How is the teacher's assessment toward the developed an authentic assessment instrument of the psychomotor domain?

\section{Research Objectives}

1. To know the procedures in developing an authentic assessment instrument of the psychomotor domain for learning physics on measurement material in class X SMA.
2. To find out the teacher's assessment toward the developed an authentic assessment instrument of the psychomotor domain?

\section{The Goal of Product Specification}

1. The developed assessment instrument is an authentic assessment instrument in the psychomotor domain that is adjusted to authentic activities.

2. The developed of an authentic assessment instrument of the psychomotor domain is completed with instructions for use and guidelines for implementing the authentic learning activities.

\section{The Importance of Development}

The expected research benefits are:

1. Increase the knowledge of the researchers on how to develop an authentic assessment instrument in the psychomotor domain.

2. As input for teachers and prospective teachers in trying and developing an authentic assessment instrument in the psychomotor domain.

3. Providing information for further research.

\section{Research Limitation}

The limitation of the research are:

1. In conducting the research, the article limits the scope of class X students in SMAN 1 Muaro Jambi.

2. Chose the measurement material for 2015 on an odd semester to be developed into an authentic assessment instrument.

3. Chose the 2013 curriculum as the basis for developing an authentic assessment instrument of the psychomotor domain on the measurement material.

4. The authentic assessment instrument developed specifically for the psychomotor domain.

\section{METHOD}

The research type was Research and Development (R \& D). The developmental model is a research method used to produce products and test the feasibility of the products (Sugiyono, 2009). The steps of the research used Dick and Carey developmental model, which consisted of ten stages. They are (1) analysis the learning objectives, (2) learning analysis, (3) analysis of students and their environment, (4) formulating specific objectives, (5) developing assessment instruments, (6) developing learning strategy, (7) developing and selecting learning materials, (8) formative evaluation, (9) revision, and (10) summative evaluation. But, the article used only nine of ten stages. The last steps did not take due to the summative evaluation is considered as sufficient to determine the feasibility of a product, both theoretically and empirically. Setyosari (2010) argues that "the tenth step, the summative evaluation, is used to test the 
effectiveness of the overall design, process, program, which requires external test or evaluation." Thus, it obtained a level of efficiency, effectiveness, and attractiveness of the overall design, process, and program.

\section{Trial Design}

Product trials intended to find out the effectiveness and efficiency of the developed product. Design validation was provided by two experts and a physics teacher. Product trials carried out to 10 students of class $\mathrm{X}$ in the first semester of SMA N 1 Muaro Jambi.

\section{Trial Subject}

The trial subjects were small group trials. The subjects were ten students of class $\mathrm{X}$ students in SMAN 1 Muaro Jambi.

\section{Type of Data}

The data were qualitative and quantitative data. Qualitative data were responses, and suggestions/input provided by the experts' validation team in terms of language, construction, practicality, and objectivity on the product of authentic assessment instruments for the psychomotor domain. And, the data also obtained from teachers who provided suggestions and responses to the developed products. Meanwhile, quantitative data were the quality of the validity and practicality of the developed instruments, namely: instrument validation questionnaire data for the validation sheet, validation sheet for products, and observation data of students' psychomotor during practicum.

\section{Data collection instruments}

Data collection instruments were:

a. The questionnaire was provided to the physics teacher on the assessment during the physics learning process.

b. An instrument of validation questionnaire by experts team consists of questions related to the developed product completed with comments and suggestions for product improvement.

c. An authentic assessment instrument for the psychomotor domain, namely the validated products by experts team and used during the learning process.

d. Student worksheets of a systematic work step sequence and used as practicum guide by students on measurement material.

e. Questionnaire of teacher response aimed to find out and measure the quality of the instrument in practical terms.

\section{RESULT \\ Presenting the Result of Trial}

The results of the developmental research were (1) assessment instruments for psychomotor domain on material measurement of the physic subject on class X MIA, (2) Student worksheets, and (3) questionnaires for teacher response of statement sheets on psychomotor assessment instruments. The developing of this product instrument used the Dick \& Carey (2009) development model through 9 stages, namely:

\section{Identification of Learning Objectives}

Based on the results of the interview with a physic teacher at SMA Negeri 1 Muaro Jambi, found that the school used the curriculum 2013. Therefore, the basic competencies in the syllabus are developed into indicators of learning achievement.

a.Basic Competence 4.1

b.Present the results of measurements of physical quantities using appropriate equipment and techniques for scientific investigations.

c. Indicator: (1) students can determine the accuracy of the ruler, calipers, and screw micrometer. (2) Students can perform measurements using a ruler, calipers, and screw micrometer. (3) Students can report the measurement results of using a ruler, calipers, and screw micrometer. (4) Students can use experimental equipment according to their function. (5) Students can maintain equipment safety and life safety. (6) Students can clean up the experimental equipment. And, (7) Students can keep the environment clean after experimenting

\section{Learning analysis}

The learning analysis of students in SMA Negeri 1 Muaro Jambi was:

1. All process of practicum activities takes place in the laboratory

2. Each material has a practicum activity.

3. Practicum activities are supported by the availability of equipment and experimental materials in the laboratory but, the guidelines for practicum activity have not been compiled or recorded into student worksheets and usually only using a sheet with simple practical steps. Also, in the assessment process, the teacher used a simple rubric and might not yet accommodate to assess the students' psychomotor abilities in more detail.

\section{Analysis of students and their environment}

Based on an interview with a physics teacher at SMA Negeri 1 Muaro Jambi, it obtained the following data:

1. Students have the same habits and background of knowledge. 
2. The characteristics of students are heterogeneous. Most students have a strong curiosity but some of them are not.

3. Students are very active and enthusiastic during the practicum activities.

\section{Formulating the learning objectives}

The steps at this stage found out the curriculum used by the school to adjust the contents of the Psychomotor Assessment Instrument and competencies. The data obtained from an interview with a physics teacher at SMA Negeri 1 Muaro Jambi, that the school used the 2013 curriculum. The formulating the learning objectives followed the syllabus of the 2013 curriculum used in SMA Negeri 1 Muaro Jambi.

\section{Developing assessment instruments}

The developing stage started from designing the product, determining the technique, form, and components of the instrument by considering the detail of the stages of product development.

The specification of the instrument design was the stage of product making. The product was an assessment instrument for the psychomotor domain using non-test techniques, including observation sheets, worksheets, and a teacher's response questionnaire to the developed product instrument.

Furthermore, the product was validated by 2 experts. Then, it continued to product revision on draft 1 following the experts' suggestions and produced draft 2. After that, the draft 2 was validated by 2 experts. The expert stated, theoretically the draft 2 that has been tested feasible to use, which later, draft 2 became a product at the development stage.

\section{Developing learning strategies}

The researchers used a strategy or experimental learning method at this stage, which was selected as appropriate with the process of practicum. The experimental learning started from pre-learning activities, which were preparing students, types of equipment and materials experimenting, and writing the results of the experiment.

\section{Developing or selecting teaching materials into Student Worksheet}

The selecting of teaching materials must follow the results of the need analysis and students' characteristics, especially at SMA Negeri 1 Muaro Jambi. The chosen teaching material was a student worksheet for physics learning, particularly in measurement material. The stages in developing students worksheets were; making the cover and content containing title, objectives, the materials, equipment and materials, work procedures, and data analysis that will be performed by students.

\section{Conduct formative evaluation}

After the product making stage, a formative evaluation carried out in the eighth stage, which aims to determine the weaknesses of the product. At this stage, an evaluation was carried out toward the design by asking for suggestions and opinions from experts/validators regarding content, construct, language, objectivity, and practicality.

\section{Analysis of the validation data of assessment instruments for psychomotor domain}

The experts were Drs. Maison, M.Si, Ph.D., and Haerul Pathoni, S.Pd., M.Pfis, which played as a validator. The validator assessed the product in a validation sheet. There were seven aspects of validation, including language, material, construction, objective, systematic, practicality, and financing. The total score of validation I from validator 1 and validator 2 was 123 of 150 (highest score). The score was in the category of $103 \leq \mathrm{N}$ <126: "Good." Meanwhile, for validation II, it obtained 136 of 150 (highest score) and included in the category of $127 \leq \mathrm{N}<150$ : "Very Good."

Analysis of validation data of Student Worksheet

This stage selected the same experts as the previous stage. They were Drs. Maison, M.Si, Ph.D., and Mr. Haerul Pathoni, S.Pd., M.PFis. The expert assessed the design in a validation sheet. There were three aspects of assessment, including language, content, and procedures. The total score of validation I from validator 1 and validator 2 was 114 of 150 (highest score). The score was in the category of $95 \leq \mathrm{N}<118$ "Good." Meanwhile, for validation II, it obtained 127 of 150 (highest score) and included in the category of $119 \leq \mathrm{N}<140$ :" Very Good."

\section{Product trials}

Product trials were carried out to small groups, which randomly selected 10 students of class X MIA 7 in SMA N 1 Muaro Jambi. The class selection was carried out by the physics teacher, Mrs. Ririn Munthomimah, S.Pd, M.Pd. The product trial aims to determine the teacher's assessment of the developed instrument.

The application of the product was carried out by filling out the observation sheet by the observer and different students. The results of trials in class $\mathrm{X}$ MIA 7 at SMA 1 Muaro Jambi were from the teacher's response questionnaire toward the product. 


\section{Analysis of the Teacher's Response Questionnaire}

Data qualitative obtained from the analysis of the teacher's response questionnaire. This data was obtained from a physics teacher who taught in class X, Mrs. Ririn Munthomimah, S.Pd, M.Si. as a user of the product at SMA N 1 Muaro Jambi. The data, on the practicality aspect, was generally good, but there were some suggestions from respondents. The mean of the teacher's response was $82 \%$ of 100 (highest percentage). Then, the criteria for the percentage of assessment included in the category $81 \% \leq \mathrm{NRG}<100 \%$, and the category of "very strong" or positive.

\section{Revision to the product instrument}

The revision was carried out following the suggestions provided by validators and the trial results to students. The revision included the construct or appearance of the Instrument and Student Worksheet, the language or sentence, and the material.

\section{CONCLUSION}

The conclusions from this development research were: (1) The process of product development used nine stages: analysis of the learning objectives, learning analysis, analysis of students and their environment, formulating specific objectives, developing assessment instruments, developing learning strategy, developing and selecting learning materials, formative evaluation, and revision, and (2) the product instrument had validity with the criteria of "very good." Also, this assessment instrument had "very strong" practicality criteria, which means the assessment instrument was positive with a percentage of the teacher's response score of $82 \%$. In this case, the teacher supported the development of the assessment instrument for the psychomotor domain.

The article suggested (1) Psychomotor assessment was used as a tool to assess the physics subjects, but, it may use as a guideline for other subjects that conduct psychomotor assessments, (2) Psychomotor assessment used in SMA N 1 Muaro Jambi and can also use in other high schools with the same characteristics, and (3) The assessment in observing the psychomotor of students required the assistance of a teacher's assistant to make observations aiming the observation is more accurate and efficient.

\section{REFERENCES}

Abidin, Y. (2014). Desain Sistem Pembelajaran Dalam Konteks Kurikulum 2013. Bandung: Radika Aditama.

Fatonah, S., Suyata, P., \& Prasetyo, Z. K., (2013), Developing an Authentic Assessment Model in Elementary School Science Teaching, Journal of Education and Practice, 4 (13), 50 - 61 .

Masyitah. (2012). Pengembangan Instrumen Penilaian Autentik Mata Pelajaran Kimia di SMA N 4 Kota Jambi. Skripsi. PMIPA FKIP Universitas Jambi: Jambi.

Ovianti, Suci, Merinda. (2013). Pengembangan Instrumen Penilaian Autentik Pada Proses dan Hasil Pembelajaran Matematika Materi Persamaan Garis Lurus di Kelas VII SMP Berdasarkan Standar KTSP. Skripsi. PMIPA FKIP Universitas Jambi: Jambi

Setyosari, P. (2010). Metode Penelitian Pendidikan dan Pengembangan. Jakarta: Kencana Prenada Media Group

Sugiyono. (2009). Metode Penelitian Pendidikan Pendekatan Kuantitatif, Kualitatif, dan R\&D. Bandung: Alfabeta. 